\title{
Functional characterization of histamine receptor subtypes in a human bronchial epithelial cell line
}

\author{
TOBIAS MÜLLER ${ }^{1 *}$, DANIEL MYRTEK $^{1 *}$, HANNES BAYER $^{3}$, STEPHAN SORICHTER $^{1}$, KATRIN SCHNEIDER $^{1}$, \\ GERNOT ZISSEL ${ }^{1}$, JOHANNES NORGAUER ${ }^{2}$ and MARCO IDZKO $^{1}$ \\ ${ }^{1}$ Department of Pneumology, University of Freiburg, Freiburg; ${ }^{2}$ Department of Dermatology, \\ University of Jena, Jena; ${ }^{3}$ Department of Dermatology, University of Muenster, Muenster, Germany
}

Received April 14, 2006; Accepted June 1, 2006

\begin{abstract}
Histamine is a well-known mediator eliciting a broad range of responses in different cell types. Four different subtypes of $\mathrm{G}$ protein-coupled histamine receptors $\left(\mathrm{H}_{1}-\mathrm{H}_{4}\right)$ have been cloned and pharmacologically characterized. However, involvement of the different histamine receptor subtypes in immunomodulatory functions of bronchial epithelium has only been investigated marginally. The expression and function of histamine receptor subtypes on the human bronchial epithelial cell line BEAS-2B was analyzed by PCR, intracellular $\mathrm{Ca}^{++}$-measurements and ELISA. We show mRNA expression of the histamine receptor subtypes $\mathrm{H}_{1}, \mathrm{H}_{2}$, and $\mathrm{H}_{3}$, but not $\mathrm{H}_{4}$ in the human bronchial epithelial cell line BEAS-2B. Using intracellular $\mathrm{Ca}^{++}$-measurements, we demonstrated functional expression of the $\mathrm{H}_{1}$ and $\mathrm{H}_{3}$ receptors. To characterize the biological properties of histamine in airway epithelial biology, we also investigated its effects on cytokine secretion by BEAS-2B cells. Thereby, we were able to show up-regulation of the proinflammatory mediators IL-6 and CXCL8/ IL-8 via activation of the $\mathrm{H}_{1}, \mathrm{H}_{2}$ and $\mathrm{H}_{3}$ receptor subtypes. The Th1 cytokines CXCL9/MIG and CXCL10/IP-10 and the chemokine CCL5/RANTES were regulated in a distinct manner: Whereas histamine inhibited the IFN- $\gamma / \mathrm{TNF}-\alpha$-induced secretion of MIG via the histamine receptor subtypes $\mathrm{H}_{1}, \mathrm{H}_{2}$, and $\mathrm{H}_{3}$, the histamine-induced suppression of RANTES was due to activation of the $\mathrm{H}_{2}$ and $\mathrm{H}_{3}$ receptors, while reduction of cytokine-triggered IP-10 secretion was mediated only by triggering the $\mathrm{H}_{2}$ receptor. In summary our data provide evidence that histamine released during allergic lung diseases exerts regulatory influence on airway epithelial cells.
\end{abstract}

Correspondence to: Dr Marco Idzko, Department of Pneumology, Medical University Hospital Freiburg, Killianstr. 5, 79106 Freiburg, Germany

E-mail: idzko@med1.ukl.uni-freiburg.de

${ }^{*}$ Contributed equally

Key words: histamine, histamine receptors, airway epithelial cells, BEAS-2B

\section{Introduction}

Histamine [2-(4-imodazole)-ethylamine], one of the most intensely studied molecules in medicine, is a preformed mediator stored primarily in the cytoplasmic granules of basophils and mast cells (1). It is released upon activation of IgE receptors or stimulation with degranulating agents such as complement components, neuropeptides and cytokines. Histamine plays an essential role in cell-mediated immunity, but it is also involved in inflammatory lung diseases such as bronchial asthma (2-4).

The pleiotropic effects of histamine are mediated by different histamine membrane receptors. Four different subtypes of $\mathrm{G}$ protein-coupled histamine receptor, designated $\mathrm{H}_{1}$, $\mathrm{H}_{2}, \mathrm{H}_{3}$, and $\mathrm{H}_{4}$, have been described and pharmacologically characterized $(5,6)$.

The $\mathrm{H}_{1}$ receptor which is coupled to pertussis toxininsensitive $\mathrm{Gq} / 11$-proteins mediates most of the proinflammatory effects of histamine (7). Anti-inflammatory and immunosuppressive effects of histamine, such as inhibition of IL-12 secretion or induction of IL-10 production by dendritic cells, are mostly dependent on stimulation of the $\mathrm{H}_{2}$ receptor, which is coupled to the adenylate cyclase pathway $(8,9)$. The $\mathrm{H}_{3}$ receptor elicits an increase in intracellular $\mathrm{Ca}^{++}$ concentration via activation of pertussis toxin-sensitive $\mathrm{Gi}$ / o-proteins. Furthermore, it is involved in the regulation of cytokine release from alveolar macrophages, mast cells, and dendritic cells (10). Previously, we demonstrated functional expression of the histamine receptors $\mathrm{H}_{1}, \mathrm{H}_{2}$, and $\mathrm{H}_{3}$ in human monocyte-derived dendritic cells (DCs). Recently, functional expression of the $\mathrm{H}_{4}$ receptor on dendritic cells was shown, but its exact signal transduction pathways remain unclear (11).

Asthma is a lung disease characterized by acute bronchoconstriction, bronchial hyperreactivity and airway inflammation, leading to remodeling of the airways (12). The respiratory epithelium is believed to be important in the pathogenesis of allergic airway diseases since it is the first tissue to meet inhaled allergens (13). It has been shown previously that airway epithelial cells are capable of secreting a variety of mediators, including proinflammatory cytokines and chemokines. Therefore, they participate in the recruitment of different leukocytes into inflamed tissue $(14,15)$. In 
this context, mediators such as interleukin (IL)-6, CXCL8/IL-8, CCL5/RANTES (regulated upon activation normal T-cell expressed and secreted) $(16,17)$ or the Th1-chemokines CXCL10/IP-10 (interferon-inducible protein-10) and CXCL9/ MIG (monokine induced by $\gamma$-interferon) $(14,18,19)$ play a prominent role. Airway epithelial cells from asthmatic patients have been shown to express a different pattern of proinflammatory cytokines compared to healthy individuals (20). Release of proinflammatory cytokines from airway epithelium can be provoked by a variety of agents, including proteases secreted by neutrophils, eosinophil granule proteins, or mast cell products such as histamine $(18,21)$. However, little is known about the expression of the different histamine receptor subtypes on bronchial epithelial cells and their involvement in the activation of these cells.

To investigate the expression and function of histamine receptors on bronchial airway epithelial cells BEAS-2B cells were used. This adenovirus-12 SV40 hybrid virus transformed human bronchial epithelial cell line is widely used to explore the functional properties of bronchial epithelial cells $(18,22)$. Furthermore, the aim of the present study was to characterize involvement of different histamine receptors in cellular responses and cytokine production.

\section{Materials and methods}

Materials. BEAS-2B cells were obtained from the Deutsche Sammlung von Mikroorganismen und Zellkulturen (Braunschweig, Germany). Human recombinant IFN- $\gamma$ was obtained from Immuntools (Friesoythe, Germany) and recombinant TNF- $\alpha$ was from Strathmann Biotec (Hannover, Germany). Histamine and betahistine were obtained from Sigma (Deisenhofen, Germany), Dimaprit and (R)- $\alpha$-methylhistamine (R- $\alpha-\mathrm{MeH})$ were purchased from ICN Biomedicals (Costa Mesa, CA, USA). ELISA kits for human CXCL8/IL-8, CXCL10/IP-10, CXCL9/MIG and CCL5/RANTES were purchased from R\&D Systems (Minneapolis, USA). Matched pairs for human IL-6 were obtained from Immuntools .

Cell culture and stimulation. BEAS-2B cells were grown in MEM-medium (Gibco, Paisley, UK) containing 5\% fetal calf serum gold (PAA Laboratories, Pasching, Austria) and 1\% penicillin/streptomycin (Biochrom, Berlin, Germany) in $175-\mathrm{cm}^{2}$ culture flasks (BD Falcon, Bedford, USA) at $37^{\circ} \mathrm{C}$, $5 \% \mathrm{CO}_{2}$ and $100 \%$ humidity, as described previously (23). To favor cell adhesion, flasks were coated with a solution containing $30 \mu \mathrm{g} / \mathrm{ml}$ rat collagen $\mathrm{S}, 1 \mathrm{mg} / \mathrm{ml}$ human fibronectin and $100 \mu \mathrm{g} / \mathrm{ml} \mathrm{BSA}$ in MEM-medium. For subculture trypsin/ EDTA-solution (Biochrom) was used to remove adherent cells. For subsequent experiments cells were seeded into 24-well tissue culture plates (Corning inc., Corning, USA), at a density of $0.10 \times 10^{6}$ cells/well. After $4 \mathrm{~h}$ of adherence, cells were serum-starved overnight. Then medium was changed and cells were stimulated. After an additional $24 \mathrm{~h}$, cell supernatants were collected and stored at $-70^{\circ} \mathrm{C}$ until analysis by ELISA.

Intracellular $\mathrm{Ca}^{++}$-measurements. $\mathrm{Ca}^{++}$transients were measured in BEAS-2B cells loaded with the $\mathrm{Ca}^{++}$indicator fura-2/AM (Calbiochem, La Jolla, California, USA) by using

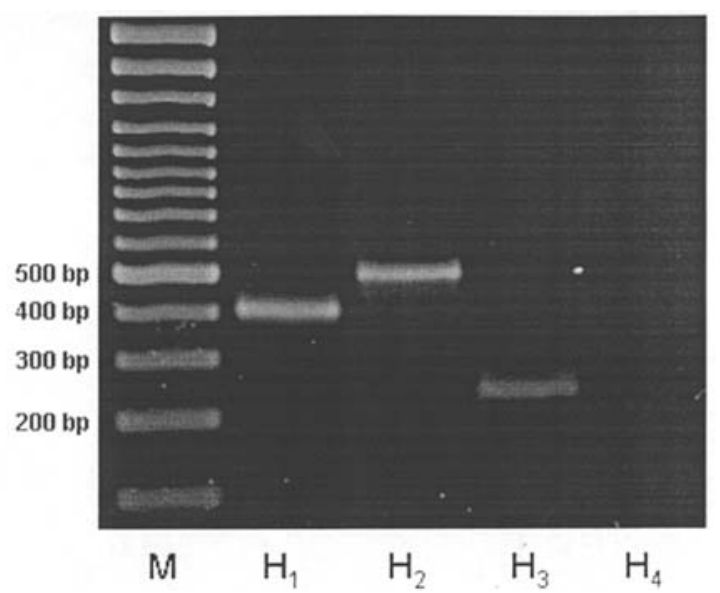

Figure 1. Expression of mRNA for different histamine receptor subtypes in BEAS-2B cells. Using cDNA of BEAS-2B cells, the expression of $\mathrm{H}_{1}, \mathrm{H}_{2}$, and $\mathrm{H}_{3}$ but not $\mathrm{H}_{4}$ histamine receptors was detected by RT-PCR. Experiments were repeated 2 times with identical results.

the digital fluorescence microscope unit Attofluor (Zeiss, Oberkochen, Germany). Briefly, BEAS-2B cells were incubated with $2 \mu \mathrm{M}$ Fura-2/AM for $30 \mathrm{~min}$ at $37^{\circ} \mathrm{C}$ in a $\mathrm{Ca}^{++}$- and $\mathrm{Mg}^{++}$-free Hanks' BSA solution. Cells were then washed twice and finally resuspended in the same buffer containing $1.5 \mathrm{mM} \mathrm{CaCl}_{2}$ and $1.5 \mathrm{mM} \mathrm{MgCl}_{2}$. Traces were followed spectrofluorometrically and $\mathrm{Ca}^{++}$transients were determined by multiple cell acquisitions with the 340/380 wavelength excitation ratio at an emission wavelength of $505 \mathrm{~nm}$. Curves shown are representative of the whole cell population.

Cytokine assays. IL-6, IL-8, IP-10, MIG, and RANTES were measured by ELISA and performed according to the manufacturer's recommendations. Samples were assayed in duplicate for each condition.

Analysis of mRNA expression. Total RNA was extracted from the cells using Trizol-reagent (Gibco, Paisley, UK) as instructed by the manufacturer. To obtain cDNA, $5 \mu \mathrm{g}$ of total RNA were primed with oligo-dT primers (Hermann GbR, Freiburg, Germany) and reverse transcribed with StrataScript reverse transcriptase (Stratagene, La Jolla, USA). Primers for the different human histamine receptors were designed based on published sequence data $\left(\mathrm{H}_{1}\right.$ : NM_000861, $\mathrm{H}_{2}$ : NM_022304, $\mathrm{H}_{3}$ : NM_007232, H4: NM_021624) employing Primer3-software (http://frodo.wi.mit.edu/cgi-bin/primer3/primer3_www. cgi) retrieving the following sequences: $\mathrm{H}_{1}$ receptor (403-bp product), sense 5'-CATTCTGGGGGCCTGGTTTCTCT-3', antisense 5'-CTTGGGGGTTTGGGATGGTGACT-3'; $\mathrm{H}_{2}$ receptor (497-bp product), sense 5'-CCCGGCTCCGCAAC CTGA-3', antisense 5'-CTGATCCCGGGCGACCTTGA-3'; $\mathrm{H}_{3}$ receptor (221-bp product), sense 5'-CTTCCTGCCCTA GCAGTT-3', antisense 5'-GCAGAGAACAGCTTCGAGG TT-3'; $\mathrm{H}_{4}$ receptor (184-bp product), sense 5'-TCGAATGG GATTTTGGAAAG-3', antisense 5'-ACGGCCACCATCAG AGTAAC-3'.

PCR was performed using $10 \mu \mathrm{l}$ of iQ-Supermix (BioRad, Hercules, USA), $7 \mu 1 \mathrm{H}_{2} \mathrm{O}, 1 \mu \mathrm{l}$ of each primer (final 
A

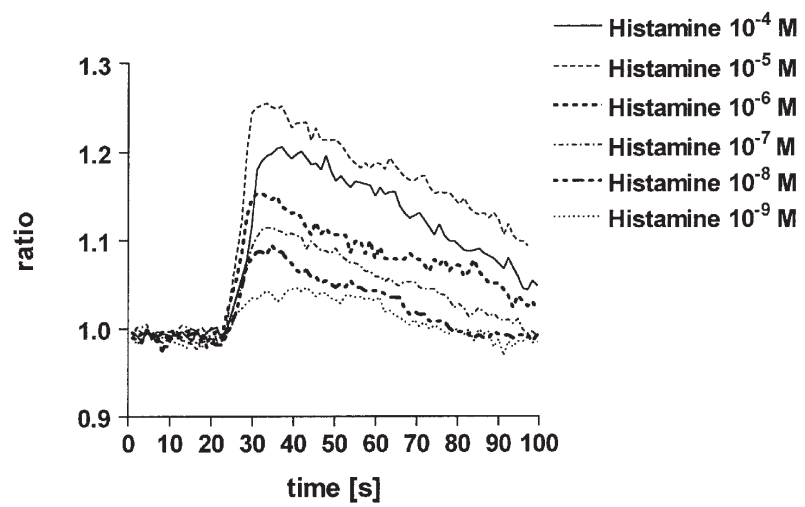

B

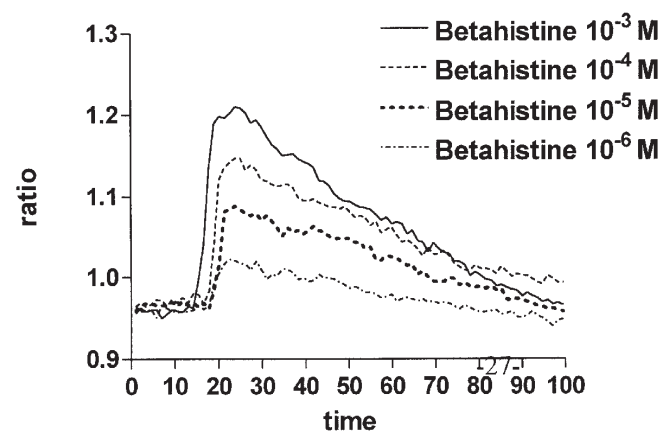

Figure 2. Intracellular $\mathrm{Ca}^{++}$mobilization in BEAS-2B cells. BEAS-2B cells were stimulated with different concentrations of (A) histamine or the histaminergic agonists (B) betahistine ( $\mathrm{H}_{1}$ receptor agonist), (C) $\mathrm{R}-\alpha-\mathrm{MeH}$ $\left(\mathrm{H}_{3}\right.$ receptor agonist) or (D) dimaprit $\left(\mathrm{H}_{2}\right.$ receptor agonist). (E) Influence on intracellular $\mathrm{Ca}^{++}$mobilization by histamine $\left(10^{-4} \mathrm{~mol} / \mathrm{l}\right)$ after preincubation with diphenhydramine $\left(\mathrm{H}_{1}\right.$ receptor antagonist $)$, cimetidine $\left(\mathrm{H}_{2}\right.$ receptor antagonist) or thioperamide $\left(\mathrm{H}_{3}\right.$ receptor antagonist). One representative of 3 similar experiments is shown. ${ }^{*}$ Statistical significance compared $(\mathrm{p}<0.05)$ to cells stimulated with histamine only.

concentration $0.5 \mu \mathrm{M}$ each) and $1 \mu \mathrm{l}$ of cDNA. Amplification conditions were 12 -min initial denaturation at $95^{\circ} \mathrm{C}$ followed by 40 cycles of denaturation $\left(94^{\circ} \mathrm{C}\right)$ for $30 \mathrm{sec}$, annealing $\left(60^{\circ} \mathrm{C}, \mathrm{H}_{1} / \mathrm{H}_{2} ; 62^{\circ} \mathrm{C}, \mathrm{H}_{3} ; 57^{\circ} \mathrm{C}, \mathrm{H}_{4}\right)$ for $30 \mathrm{sec}$ and amplification $\left(72^{\circ} \mathrm{C}\right)$ for $45 \mathrm{sec}$. PCR-products were subjected to electrophoresis on a $2.5 \%$ agarose gel and visualized by ethidium bromide staining.

\section{Results}

$B E A S-2 B$ cells express different histamine receptor subtypes. Expression of mRNA for the different histamine receptor subtypes in BEAS-2B cells was analyzed using RT-PCR. As shown in Fig. 1, BEAS-2B cells express $\mathrm{H}_{1}, \mathrm{H}_{2}$, and $\mathrm{H}_{3}$ but not $\mathrm{H}_{4}$ receptors. To confirm that the negative result was not due to incorrect experimental conditions, PCR was also performed with cDNA from human monocyte derived dendritic cells leading to the expected products for the $\mathrm{H}_{4}$ receptor (data not shown).

Histamine induces intracellular $\mathrm{Ca}^{++}$mobilization. Changes in intracellular $\mathrm{Ca}^{++}$are crucial for cellular responses such as
C

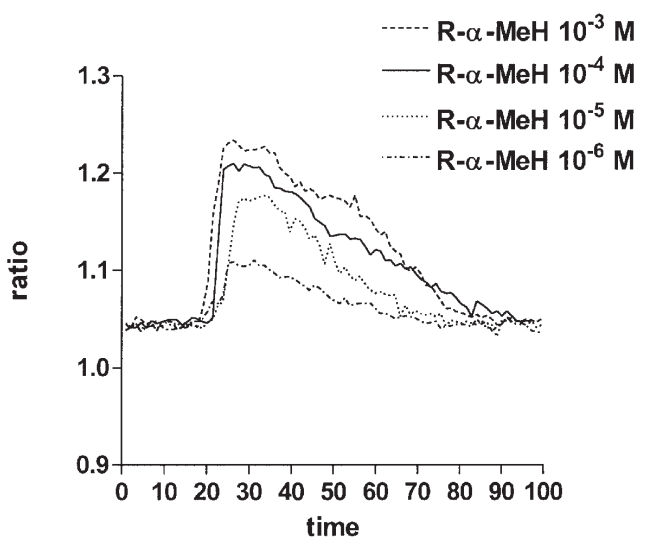

D

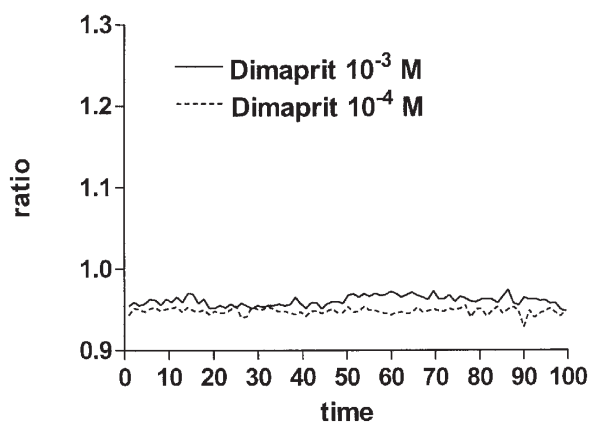

$\mathbf{E}$

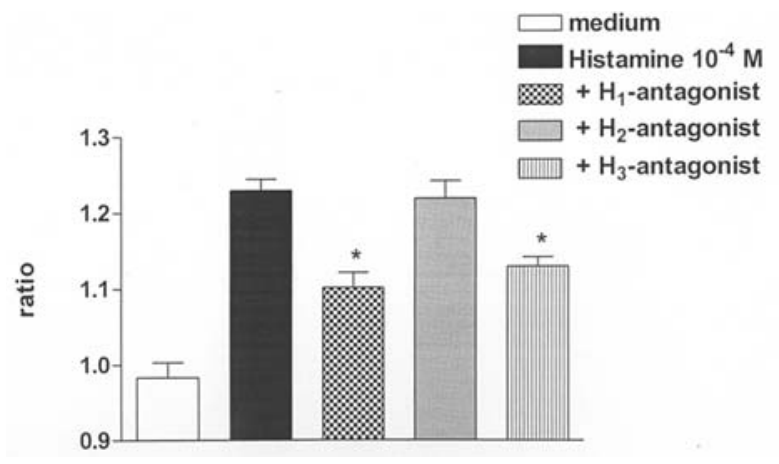

the release of cytokines or chemokines. Therefore, intracellular $\mathrm{Ca}^{++}$transients after stimulation with histamine were analyzed in fura-2-labeled BEAS-2B cells, using digital fluorescence microscopy. According to previous publications (9), histamine induced a rapid time- and concentration-dependent increase in intracellular $\mathrm{Ca}^{++}$(Fig. 2A). Maximal and half-maximal responses were at $10^{-5} \mathrm{~mol} / 1$ and $10^{-7} \mathrm{~mol} / 1$ histamine concentrations, respectively. To identify the histamine receptor subtypes involved in intracellular $\mathrm{Ca}^{++}$changes, BEAS-2B cells were stimulated with selective histamine receptor agonists. Fig. 2B shows that the $\mathrm{H}^{1}$ receptor agonist betahistine induced a spiking concentration-dependent $\mathrm{Ca}^{++}$rise followed by a slow time-dependent declining phase. In addition, the $\mathrm{H}_{3}$ receptor agonist $\mathrm{R}-\alpha-\mathrm{MeH}$ was also able to increase intracellular $\mathrm{Ca}^{++}$levels in a dose-dependent manner which was also followed by a slow time-dependent declining phase (Fig. 2C). In contrast, the $\mathrm{H}_{2}$ receptor agonist dimaprit was not able to trigger an intracellular $\mathrm{Ca}^{++}$increase (Fig. 2D). Moreover, preincubation with diphenhydramine or thioperamide, which are $\mathrm{H}_{1}$ and $\mathrm{H}_{3}$ receptor antagonists, respectively, significantly reduced the histamine-induced calcium transient (Fig. 2E). In contrast, the $\mathrm{H}_{2}$ receptor antagonist cimetidine was ineffective. 
A

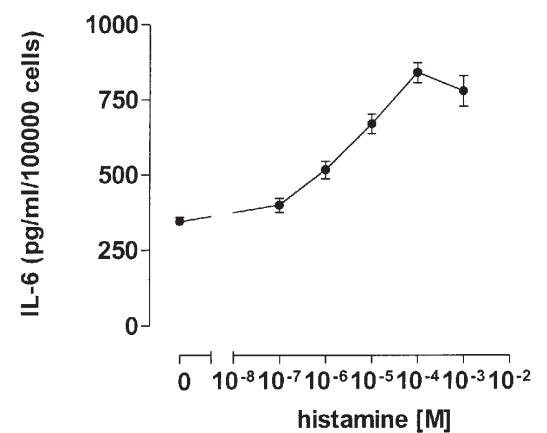

B

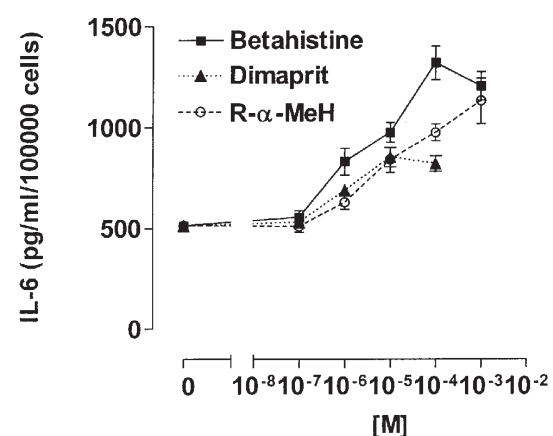

Figure 3. Modulation of IL-6 production by histamine. BEAS-2B cells $\left(1 \times 10^{5}\right)$ were stimulated with the indicated concentrations of (A) histamine or (B) the histaminergic agonists betahistine $\left(\mathrm{H}_{1}\right.$ receptor agonist), dimaprit $\left(\mathrm{H}_{2}\right.$ receptor agonist), and $\mathrm{R}-\alpha-\mathrm{MeH}\left(\mathrm{H}_{3}\right.$ receptor agonist), respectively. Supernatants were collected after $24 \mathrm{~h}$ and IL- 6 content was determined by ELISA. One representative of 3 similar experiments is shown.

Stimulation of Beas-2B with histamine, betahistine or R- $\alpha-\mathrm{MeH}$ in a $\mathrm{Ca}^{++}$-free ethyleneglycol-bis-(aminoethylether)- $\mathrm{N}, \mathrm{N}, \mathrm{N}^{-}$tetraacetic acid (EGTA)-containing saline solution $(4 \mathrm{mmol} / \mathrm{l}$ EGTA) did not abrogate the histamine-induced intracellular $\mathrm{Ca}^{++}$transients, suggesting that the $\mathrm{Ca}^{++}$rise was due to $\mathrm{Ca}^{++}$ mobilization from the intracellular stores (data not shown).

Modulation of IL-6 and IL-8 release by histamine. It was previously shown that histamine influences the release of cytokines/chemokines, e.g. in fibroblasts, monocytes, lymphocytes or dendritic cells. As shown in Fig. 3A and 4A, histamine induces the secretion of the proinflammatory mediators IL- 6 and IL-8 in a dose-dependent manner. In both cases, this effect was mimicked by the $\mathrm{H}_{1}$ receptor agonist betahistine, the $\mathrm{H}_{2}$ receptor agonist dimaprit, and the $\mathrm{H}_{3}$ receptor agonist R- $\alpha-\mathrm{MeH}$, respectively (Fig. 3B and 4B).

Modulation of chemokine production by histamine. Bronchial epithelial cells are known to produce the chemokines RANTES, IP-10, and MIG, attracting preferably Th1-lymphocytes. As previously described, expression of these chemokines by BEAS-2B cells could be induced by a combination of the proinflammatory cytokines TNF- $\alpha$ and IFN- $\gamma$ (100 IU/ml each) (14). Addition of histamine dose-dependently inhibited the production of IP-10 (Fig. 5C), MIG (Fig. 5D), and RANTES (Fig. 5E). Inhibition of IP-10 secretion was mimicked by the $\mathrm{H}_{2}$ receptor agonist dimaprit, whereas betahistine $\left(\mathrm{H}_{1}\right.$ receptor agonist) and ( $\mathrm{R})-\alpha$-methyl-histamine $\left(\mathrm{H}_{3}\right.$ receptor agonist) showed no influence on the IP-10 production of BEAS-2B cells (Fig. 5B). In contrast, betahistine, dimaprit, as well as
A

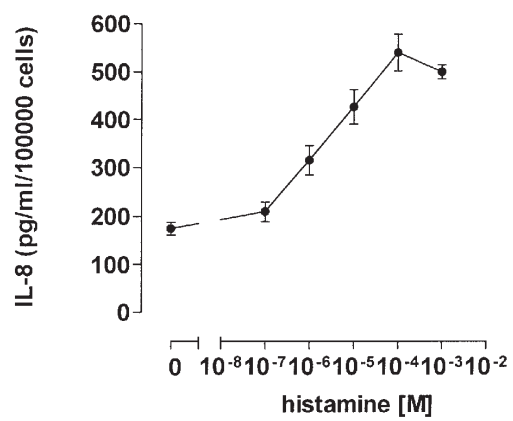

B

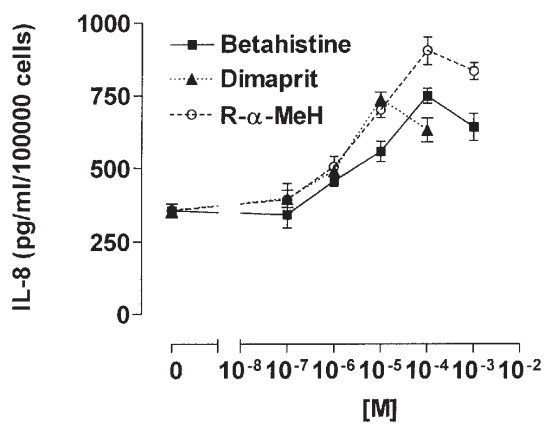

Figure 4. Modulation of IL-8 production by histamine. BEAS-2B cells $\left(1 \times 10^{5}\right)$ were stimulated with the indicated concentrations of (A) histamine or (B) the histaminergic agonists betahistine $\left(\mathrm{H}_{1}\right.$ receptor agonist), dimaprit $\left(\mathrm{H}_{2}\right.$ receptor agonist), and $\mathrm{R}-\alpha-\mathrm{MeH}\left(\mathrm{H}_{3}\right.$ receptor agonist), respectively. Supernatants were collected after $24 \mathrm{~h}$ and IL-8 content was determined by ELISA. One representative of 3 similar experiments is shown.

$\mathrm{R}-\alpha-\mathrm{MeH}$ inhibited the secretion of the chemokine MIG in a dose-dependent manner (Fig. 5D). RANTES release of BEAS-2B cells was inhibited by both dimaprit, and R- $\alpha-\mathrm{MeH}$. However the inhibitory effect could only be seen in higher concentrations (Fig. 5F).

\section{Discussion}

Histamine is a well-established mediator in various pathologies such as bronchial asthma. Following allergen exposure it is released primarily from mast cells and basophils causing acute symptoms such as bronchoconstriction, vasodilatation, and increased capillary permeability (4). Additionally, histamine influences chronic inflammatory processes by regulating numerous functions of different immune cells including proliferation, induction of adhesion molecule expression and cytokine production $(9,24,25)$. The pleiotropic effects of histamine are mediated by different subtypes of histamine membrane receptors (6). To elucidate the influence of histamine on airway epithelial cells, we investigated the expression and function of the four known histamine receptor subtypes on the bronchial epithelial cell line BEAS-2B.

The present study revealed that BEAS-2B cells express functional $\mathrm{H}_{1}, \mathrm{H}_{2}$, and $\mathrm{H}_{3}$ but not $\mathrm{H}_{4}$ receptors, which are differently coupled to mobilization of intracellular $\mathrm{Ca}^{++}$, chemokine and cytokine production. Activation of both $\mathrm{H}_{1}$ and $\mathrm{H}_{3}$ receptors triggered intracellular $\mathrm{Ca}^{++}$transients, which were insensitive to chelation of extracellular $\mathrm{Ca}^{++}$and therefore were due to $\mathrm{Ca}^{++}$mobilization from intracellular stores. In contrast, the $\mathrm{H}_{2}$ receptor was not involved in histamine-induced intracellular $\mathrm{Ca}^{++}$increase. Our results match those of a former 
A

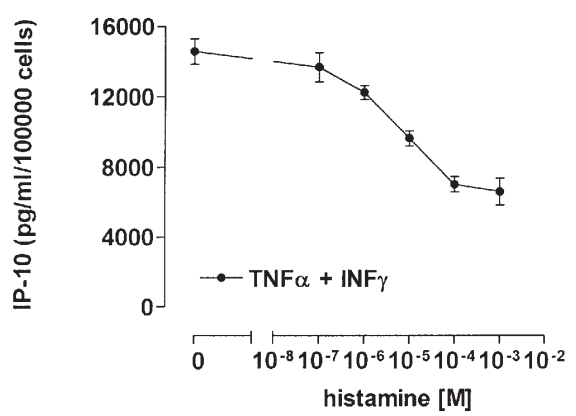

B

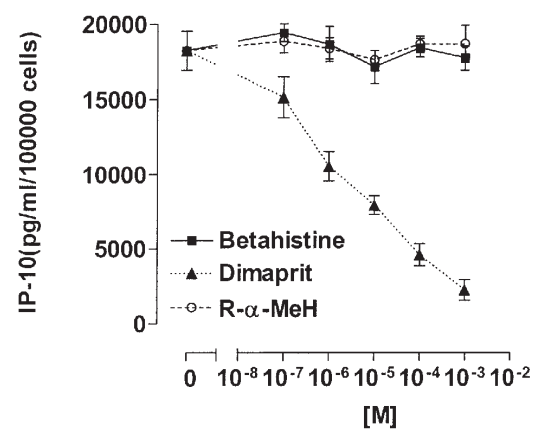

C

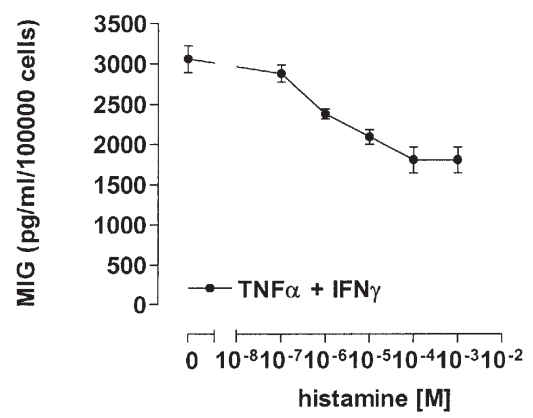

D

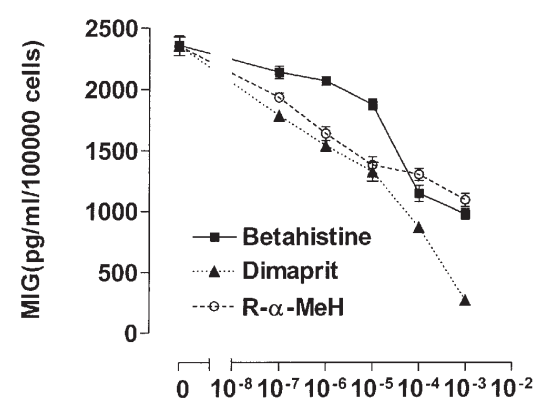

[M]

E

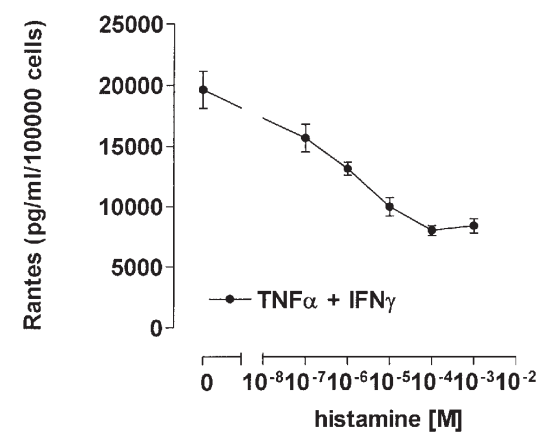

F

Figure 5. Modulation of IP-10, MIG, and RANTES by histamine. BEAS-2B cells $\left(1 \times 10^{5}\right)$ were stimulated with a combination of TNF $\alpha /$ IFN $\gamma(100 \mathrm{IU}$ each) and the indicated concentrations of (A, C and E) histamine or $(\mathrm{B}, \mathrm{D}$ and $\mathrm{F})$ the histaminergic agonists betahistine $\left(\mathrm{H}_{1}\right.$ receptor agonist), dimaprit $\left(\mathrm{H}_{2}\right.$ receptor agonist), and $\mathrm{R}-\alpha-\mathrm{MeH}\left(\mathrm{H}_{3}\right.$ receptor agonist), respectively. Supernatants were collected after $24 \mathrm{~h}$ and (A and B) IP-10, (C and D) MIG and (E and F) RANTES content was determined by ELISA. One representative of 3 similar experiments is shown.

study performed with immature dendritic cells (DCs) where $\mathrm{H}_{1}$ and $\mathrm{H}_{3}$ but not $\mathrm{H}_{2}$ receptors triggered intracellular $\mathrm{Ca}^{++}$ transients (9).

There is strong evidence, that histamine is associated with bronchial asthma as increased levels of histamine were measured in bronchoalveolar lavage (BAL) fluids of asthmatics following segmental allergen challenge. Moreover, BAL histamine levels correlate with the degree of bronchial hyperresponsiveness $(26,27)$. Inflammatory cytokines and chemokines released by airway epithelial cells have been shown to contribute significantly to the regulation of immune responses, as well as to pathological features in bronchial asthma such as airway remodeling and airway fibrosis (28). Therefore, we investigated the influence of histamine on cytokine/chemokine secretion by BEAS-2B cells. We showed that histamine as well as the $\mathrm{H}_{1}$ receptor agonist betahistine, the $\mathrm{H}_{2}$ receptor agonist dimaprit, and the $\mathrm{H}_{3}$ receptor agonist $\mathrm{R}-\alpha-\mathrm{Me}-\mathrm{H}$, dose-dependently induced secretion of the proinflammatory mediators IL-6 and IL-8, strongly suggesting an influence of histamine in inflammatory lung processes. These results match those of previous studies conducted with endothelial cells and DCs, respectively $(24,29,30)$. Furthermore, histamine triggered IL- 6 production by peripheral blood mononuclear cells and by monocyte/macrophages. Several studies have shown the importance of IL-6 and IL-8 in the pathophysiology of bronchial asthma. Allergen challenge in humans caused an IL-8-mediated increase of neutrophils in the lungs (31). In contrast, IL-6 plays a key role in airway remodeling, another classical feature of the asthmatic lung. It contributes to both subepithelial fibrosis and dyscrinie, since the regulation of mucin gene expression is mediated through an IL-6-dependent autocrine/paracrine loop (32,33).

The chemokines IP-10, MIG and RANTES are known to attract preferably Th1-lymphocytes $(34,35)$. In this study we showed that histamine inhibited the release of these chemokines in a concentration-dependent manner. Inhibition of IP-10 production was mediated solely by $\mathrm{H}_{2}$ receptors. This is consistent with a previous study showing the involvement of $\mathrm{H}_{2}$ receptors and cAMP in the regulation of IP-10 secretion (36). In contrast, modulation of MIG was also mediated by $\mathrm{H}_{1}$ and $\mathrm{H}_{3}$ histamine receptors whereas RANTES secretion was mediated by $\mathrm{H}_{2}$ and $\mathrm{H}_{3}$ histamine receptors, indicating 
differentiated regulation mechanisms represented by three of the four known receptor subtypes.

Studies on the possible role of CXCL9/MIG in inflammatory responses in the lung showed a strong association between MIG levels and the regulation of allergic airway inflammation. It was reported that the CXCR3 ligand MIG has a protective role in the development of allergic asthma. The introduction of exogenous MIG into the lungs of allergensensitized and -challenged mice greatly reduced airway hyperreactivity, eosinophil accumulation, and levels of Th2 cytokines such as IL-4, whereas levels of the Th1 cytokine IL-12 were increased. Moreover, airway neutralization of MIG at the time of allergen challenge significantly augmented airway hyperreactivity, eosinophil accumulation, and BAL levels of IL-4, whereas levels of IL-12 were significantly decreased. Therefore, MIG seems to behave as a typical Th1type chemokine as it is able to antagonize Th2-type allergic inflammation $(37,38)$. Reduced release of MIG by histamine suggests a reduced presence of Th1-lymphocytes, therefore amplifying a Th2 dominance at the site of inflammation. This could be one of the mechanisms explaining the association of histamine with bronchial asthma, for example the correlation of histamine levels with the degree of bronchial hyperresponsiveness.

CXCL10/IP-10 is also known to bind to CXCR3 and therefore attracts preferentially Th1-lymphocytes. However it was found to be up-regulated in the airways of asthmatics. A murine model of asthma revealed that the expression of IP-10 was increased in the lung after allergen challenge. Mice overexpressing IP-10 in the lung showed enhanced airway hyperreactivity, eosinophilia, and IL-4 levels compared to wild-type controls. In contrast, IP-10-deficient mice demonstrated opposite effects, with a significant reduction in these measures of Th2-type allergic airway inflammation $(39,40)$. The inhibitory effect of histamine on IP-10 secretion of BEAS-2B cells was mediated by activation of $\mathrm{H}_{2}$ receptors. These findings are consistent with the $\mathrm{H}_{2}$ receptor mediating the anti-inflammatory and immunosuppressive effects of histamine.

The role of IP-10 in the pathogenesis of asthma and its regulation by histamine is ambiguous. On the one hand, IP-10 secretion was inhibited by histamine, suggesting limited asthmatic inflammation. On the other hand, impaired chemotaxis of Th1-lymphocytes could promote a Th2-driven immune response. A possible explanation could be that inhibition of IP-10 production by histamine was mediated solely by $\mathrm{H}_{2}$ receptors, which are known to be involved in antiinflammatory and immunosuppressive processes $(8,9)$.

Our study revealed that histamine inhibited the production of CCL5/RANTES which is like MIG and IP-10 known to attract preferably Th1-lymphocytes (35). Therefore, inhibition of RANTES release by histamine could amplify Th2 dominance, leading to augmented allergic airway inflammation. In contrast, RANTES was also found to play an important role in bronchial hyperresponsiveness and allergic inflammation of the lung, especially by strongly attracting eosinophils. Furthermore, RANTES levels in BAL fluids of asthmatic children were significantly increased compared to healthy children (41). Therefore, it can be concluded that inhibition of RANTES production by histamine could also limit allergic airway inflammation by reducing the recruitment of eosino- phils. In fact, the effects of this chemokine are very versatile and sometimes controversial (42). Thus, the consequences of impaired RANTES production by histamine are complex and not fully understood at present.

The influence of histamine on secretion of chemotactic factors and the involvement of different histamine receptor subtypes underline the complex effects of histamine in human lung biology. It can be hypothesized that histamine released upon allergen challenge could activate epithelial cells, leading to enhanced release of IL-6 and IL-8, mediators known to be involved in inflammation and airway remodeling. Additionally, reduced secretion of IP-10, MIG, and RANTES, important chemotactic factors for Th1-lymphocytes could enhance a Th2-dominated surrounding.

In summary, our study provides evidence that stimulation of bronchial epithelial cells by histamine induces typical changes seen in allergy. Reduction in Th1 promoting cytokines favors allergic inflammation whereas the increase in IL-6 and IL-8 promotes airway remodeling. These effects are mediated by different histamine receptor subtypes, suggesting complex interactions of histamine released during allergic lung diseases.

\section{References}

1. Bochner BS: Systemic activation of basophils and eosinophils: markers and consequences. J Allergy Clin Immunol 106: S292-S302, 2000.

2. Jutel M, Watanabe T, Klunker S, Akdis M, Thomet OA, Malolepszy J, Zak-Nejmark T, Koga R, Kobayashi T, Blaser K and Akdis CA: Histamine regulates T-cell and antibody responses by differential expression of $\mathrm{H} 1$ and $\mathrm{H} 2$ receptors. Nature 413: 420-425, 2001.

3. Falus A and Meretey K: Histamine: an early messenger in inflammatory and immune reactions. Immunol Today 13: 154-156, 1992.

4. Williams CM and Galli SJ: The diverse potential effector and immunoregulatory roles of mast cells in allergic disease. J Allergy Clin Immunol 105: 847-859, 2000.

5. Hough LB: Genomics meets histamine receptors: new subtypes, new receptors. Mol Pharmacol 59: 415-419, 2001.

6. Hill SJ, Ganellin CR, Timmerman H, Schwartz JC, Shankley NP, Young JM, Schunack W, Levi R and Haas HL: International Union of Pharmacology. XIII. Classification of histamine receptors. Pharmacol Rev 49: 253-278, 1997.

7. MacGlashan D Jr: Histamine: A mediator of inflammation. J Allergy Clin Immunol 112: S53-S59, 2003.

8. Bury TB, Corhay JL and Radermecker MF: Histamine-induced inhibition of neutrophil chemotaxis and T-lymphocyte proliferation in man. Allergy 47: 624-629, 1992.

9. Idzko M, la Sala A, Ferrari D, Panther E, Herouy Y, Dichmann S, Mockenhaupt M, Di Virgilio F, Girolomoni G and Norgauer J: Expression and function of histamine receptors in human monocyte-derived dendritic cells. J Allergy Clin Immunol 109: 839-846, 2002.

10. Bissonnette EY: Histamine inhibits tumor necrosis factor alpha release by mast cells through $\mathrm{H} 2$ and $\mathrm{H} 3$ receptors. Am J Respir Cell Mol Biol 14: 620-626, 1996.

11. Gutzmer R, Diestel C, Mommert S, Kother B, Stark H, Wittmann $M$ and Werfel T: Histamine $\mathrm{H} 4$ receptor stimulation suppresses IL-12p70 production and mediates chemotaxis in human monocyte-derived dendritic cells. J Immunol 174: 5224-5232, 2005.

12. Fahy JV, Corry DB and Boushey HA: Airway inflammation and remodeling in asthma. Curr Opin Pulm Med 6: 15-20, 2000.

13. Kauffman HF: Interaction of environmental allergens with airway epithelium as a key component of asthma. Curr Allergy Asthma Rep 3: 101-108, 2003.

14. Sauty A, Dziejman M, Taha RA, Iarossi AS, Neote K, Garcia-Zepeda EA, Hamid Q and Luster AD: The T cellspecific CXC chemokines IP-10, Mig, and I-TAC are expressed by activated human bronchial epithelial cells. J Immunol 162: 3549-3558, 1999. 
15. Eghtesad M, Jackson HE and Cunningham AC: Primary human alveolar epithelial cells can elicit the transendothelial migration of CD14+ monocytes and CD3+ lymphocytes. Immunology 102: 157-164, 2001.

16. Stellato C, Beck LA, Gorgone GA, Proud D, Schall TJ, Ono SJ, Lichtenstein LM and Schleimer RP: Expression of the chemokine RANTES by a human bronchial epithelial cell line. Modulation by cytokines and glucocorticoids. J Immunol 155: 410-418, 1995.

17. Cromwell O, Hamid Q, Corrigan CJ, Barkans J, Meng Q, Collins PD and Kay AB: Expression and generation of interleukin8, IL-6 and granulocyte-macrophage colony-stimulating factor by bronchial epithelial cells and enhancement by IL-1 beta and tumour necrosis factor-alpha. Immunology 77: 330-337, 1992.

18. Asokananthan N, Graham PT, Fink J, Knight DA, Bakker AJ, McWilliam AS, Thompson PJ and Stewart GA: Activation of protease-activated receptor (PAR)-1, PAR-2, and PAR-4 stimulates IL-6, IL-8, and prostaglandin E2 release from human respiratory epithelial cells. J Immunol 168: 3577-3585, 2002.

19. Watkins DN, Peroni DJ, Basclain KA, Garlepp MJ and Thompson PJ: Expression and activity of nitric oxide synthases in human airway epithelium. Am J Respir Cell Mol Biol 16: 629-639, 1997.

20. Bayram H, Devalia JL, Khair OA, Abdelaziz MM, Sapsford RJ, Czarlewski W, Campbell AM, Bousquet J and Davies RJ: Effect of loratadine on nitrogen dioxide-induced changes in electrical resistance and release of inflammatory mediators from cultured human bronchial epithelial cells. J Allergy Clin Immunol 104: 93-99, 1999.

21. Noah TL, Paradiso AM, Madden MC, McKinnon KP and Devlin RB: The response of a human bronchial epithelial cell line to histamine: intracellular calcium changes and extracellular release of inflammatory mediators. Am J Respir Cell Mol Biol 5: 484-492, 1991

22. Reddel RR, Ke Y, Gerwin BI, McMenamin MG, Lechner JF, Su RT, Brash DE, Park JB, Rhim JS and Harris CC: Transformation of human bronchial epithelial cells by infection with SV40 or adenovirus-12 SV40 hybrid virus, or transfection via strontium phosphate coprecipitation with a plasmid containing SV40 early region genes. Cancer Res 48: 1904-1909, 1988.

23. Muller T, Bayer H, Myrtek D, Ferrari D, Sorichter S, Ziegenhagen MW, Zissel G, Virchow JC Jr, Luttmann W, Norgauer J, Di Virgilio F and Idzko M: The P2Y14 receptor of airway epithelial cells: coupling to intracellular Ca2+ and IL-8 secretion. Am J Respir Cell Mol Biol 33: 601-609, 2005.

24. Caron G, Delneste Y, Roelandts E, Duez C, Herbault N, Magistrelli G, Bonnefoy JY, Pestel J and Jeannin P: Histamine induces CD86 expression and chemokine production by human immature dendritic cells. J Immunol 166: 6000-6006, 2001.

25. Krouwels FH, Hol BE, Lutter R, Bruinier B, Bast A, Jansen HM and Out TA: Histamine affects interleukin-4, interleukin-5, and interferon-gamma production by human $\mathrm{T}$ cell clones from the airways and blood. Am J Respir Cell Mol Biol 18: 721-730, 1998

26. Jarjour NN, Calhoun WJ, Schwartz LB and Busse WW: Elevated bronchoalveolar lavage fluid histamine levels in allergic asthmatics are associated with increased airway obstruction. Am Rev Respir Dis 144: 83-87, 1991.

27. Casale TB, Wood D, Richerson HB, Trapp S, Metzger WJ, Zavala D and Hunninghake GW: Elevated bronchoalveolar lavage fluid histamine levels in allergic asthmatics are associated with methacholine bronchial hyperresponsiveness. J Clin Invest 79: 1197-1203, 1987.
28. Holgate ST, Lackie P, Wilson S, Roche W and Davies D: Bronchial epithelium as a key regulator of airway allergen sensitization and remodeling in asthma. Am J Respir Crit Care Med 162: S113-S117, 2000.

29. Delneste Y, Lassalle P, Jeannin P, Joseph M, Tonnel AB and Gosset P: Histamine induces IL-6 production by human endothelial cells. Clin Exp Immunol 98: 344-349, 1994.

30. Jeannin P, Delneste Y, Gosset P, Molet S, Lassalle P, Hamid Q, Tsicopoulos A and Tonnel AB: Histamine induces interleukin-8 secretion by endothelial cells. Blood 84: 2229-2233, 1994.

31. Tillie-Leblond I, Gosset P and Tonnel AB: Inflammatory events in severe acute asthma. Allergy 60: 23-29, 2005.

32. Kuhn C III, Homer RJ, Zhu Z, Ward N, Flavell RA, Geba GP and Elias JA: Airway hyperresponsiveness and airway obstruction in transgenic mice. Morphologic correlates in mice overexpressing interleukin (IL)-11 and IL-6 in the lung. Am J Respir Cell Mol Biol 22: 289-295, 2000

33. Chen Y, Thai P, Zhao YH, Ho YS, DeSouza MM and Wu R: Stimulation of airway mucin gene expression by interleukin (IL)-17 through IL-6 paracrine/autocrine loop. J Biol Chem 278: 17036-17043, 2003.

34. Bonecchi R, Bianchi G, Bordignon PP, D'Ambrosio D, Lang R, Borsatti A, Sozzani S, Allavena P, Gray PA, Mantovani A and Sinigaglia F: Differential expression of chemokine receptors and chemotactic responsiveness of type $1 \mathrm{~T}$ helper cells (Th1s) and Th2s. J Exp Med 187: 129-134, 1998.

35. Sallusto F, Lenig D, Mackay CR and Lanzavecchia A: Flexible programs of chemokine receptor expression on human polarized T helper 1 and 2 lymphocytes. J Exp Med 187: 875-883, 1998.

36. Kanda $\mathrm{N}$ and Watanabe $\mathrm{S}$ : Histamine inhibits the production of interferon-induced protein of $10 \mathrm{kDa}$ in human squamous cell carcinoma and melanoma. J Invest Dermatol 119: 1411-1419, 2002.

37. Fulkerson PC, Zimmermann N, Brandt EB, Muntel EE, Doepker MP, Kavanaugh JL, Mishra A, Witte DP, Zhang H, Farber JM, Yang M, Foster PS and Rothenberg ME: Negative regulation of eosinophil recruitment to the lung by the chemokine monokine induced by IFN-gamma (Mig, CXCL9). Proc Natl Acad Sci USA 101: 1987-1992, 2004.

38. Thomas MS, Kunkel SL and Lukacs NW: Regulation of cockroach antigen-induced allergic airway hyperreactivity by the CXCR3 ligand CXCL9. J Immunol 173: 615-623, 2004.

39. Medoff BD, Sauty A, Tager AM, Maclean JA, Smith RN, Mathew A, Dufour JH and Luster AD: IFN-gamma-inducible protein 10 (CXCL10) contributes to airway hyperreactivity and airway inflammation in a mouse model of asthma. J Immunol 168: 5278-5286, 2002.

40. Miotto D, Christodoulopoulos P, Olivenstein R, Taha R, Cameron L, Tsicopoulos A, Tonnel AB, Fahy O, Lafitte JJ, Luster AD, Wallaert B, Mapp CE and Hamid Q: Expression of IFN-gamma-inducible protein; monocyte chemotactic proteins 1,3 , and 4; and eotaxin in TH1- and TH2-mediated lung diseases. J Allergy Clin Immunol 107: 664-670, 2001.

41. Rojas-Ramos E, Avalos AF, Perez-Fernandez L, CuevasSchacht F, Valencia-Maqueda E and Teran LM: Role of the chemokines RANTES, monocyte chemotactic proteins-3 and -4 , and eotaxins- 1 and -2 in childhood asthma. Eur Respir J 22: 310-316, 2003.

42. Appay V and Rowland-Jones SL: RANTES: a versatile and controversial chemokine. Trends Immunol 22: 83-87, 2001. 